九州大学学術情報リポジトリ

Kyushu University Institutional Repository

\title{
A spherical molecular assembly formed by the interplay of hydrophobic and hydrogen bonding interactions. Formation of a hexameric ball
}

Goto, Kenta

Division of Applied Molecular Chemistry, Institute for Materials Chemistry and Engineering, Kyushu University

Miyahara, Yuji

Department of Chemistry, Graduate School of Sciences, Kyushu University

Shinmyozu, Teruo

Division of Applied Molecular Chemistry, Institute for Materials Chemistry and Engineering, Kyushu University

http://hdl. handle. net/2324/26621

出版情報：Tetrahedron Letters. 51 (5)，pp.832-835，2010-02-03. Elsevier バージョン:

権利関係: (C) 2009 Elsevier Ltd. 


\section{A Spherical Molecular Assembly Formed by the Interplay of Hydrophobic and Hydrogen Bonding Interactions. Formation of a Hexameric Ball}

Kenta Goto, ${ }^{a, *}$ Yuji Miyahara, ${ }^{b}$ and Teruo Shinmyozu ${ }^{a}$

${ }^{a}$ Division of Applied Molecular Chemistry, Institute for Materials Chemistry and Engineering, Kyushu University, 6-10-1 Hakozaki, Higashi-ku, Fukuoka 812-8581, Japan.

Tel.: +81 92642 4350; fax: +81 92642 2735; E-mail address: g2k@me.com

${ }^{\mathrm{b}}$ Department of Chemistry, Graduate School of Sciences, Kyushu University 


\section{General}

All reagents were reagent-grade and used without purification. Methanol was distilled from calcium hydride. Melting points were measured on a Yanaco MP-S3 melting point apparatus and are uncorrected. The NMR spectra were recorded on a Jeol JNM-AL300 spectrometer, operating at 300 and $75 \mathrm{MHz}$ for ${ }^{1} \mathrm{H}$ and ${ }^{13} \mathrm{C}$, respectively. The ${ }^{13} \mathrm{C}$ NMR spectra were measured on a Bruker DRX 600 spectrometer at a measurement frequency of $125 \mathrm{MHz}$. The chemical shifts are given in ppm downfield from the ${ }^{1} \mathrm{H}$ and ${ }^{13} \mathrm{C}$ signals of tetramethylsilane. The FAB mass spectra were obtained on a Jeol JMS-70 mass spectrometer with $m$-nitrobenzyl alcohol as a matrix. Elemental analyses were performed at the Center of Elementary Analysis affiliated with Faculty of Science, Kyushu University. The FT-IR spectra were recorded on a Nicolet Magna 560 spectrometer. The electrospray ionization mass spectrum was recorded on a Jeol JMS-T100CS AccuTOF spectrometer. The solid-state CPMAS ${ }^{13} \mathrm{C}$ NMR spectra were measured on a Jeol JNM-ECA400 spectrometer at a measurement frequency of $100.5 \mathrm{MHz}$ and a rotation frequency of 10 $\mathrm{kHz}$. The ${ }^{13} \mathrm{C}$ NMR chemical shifts are referenced to the methyl signal ( $\delta=17.36 \mathrm{ppm}$ ) of hexamethylbenzene, which was used as an external standard. The X-ray powder diffraction data were collected on a Rigaku MultiFlex diffactometer over the $2 \theta$ range of 5 $-60^{\circ}$ with using a copper radiation source.

\section{Synthesis}

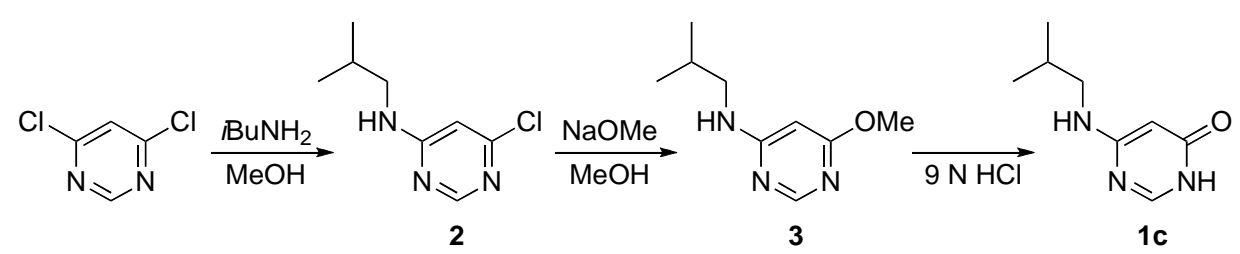

Scheme 1. Synthesis of 4-isobutylamino-6-oxopyrimidine 1c.

\section{4-Isobutylamino-6-chloropyrimidine 2}

A solution of 4,6-dichloropyrimidine ${ }^{1}(10.0 \mathrm{~g}, 67.1 \mathrm{mmol})$ in dry $\mathrm{MeOH}(200 \mathrm{~mL})$ was cooled in an ice-water bath, and then isobutylamine (10.8 g, $0.148 \mathrm{~mol})$ was added dropwise. After $10 \mathrm{~min}$, the bath was removed, and stirring was continued for $6 \mathrm{~h}$ at room temperature. After removing the solvent, the residue was partitioned between water (100 $\mathrm{mL})$ and AcOEt $(150 \mathrm{~mL})$. The aqueous phase was extracted twice with AcOEt $(100 \mathrm{~mL})$. The combined organic extracts were dried over $\mathrm{Na}_{2} \mathrm{SO}_{4}$, filtered and evaporated. The 
residue was passed through a silica gel column $(n$-hexane/AcOEt $=4: 1(\mathrm{v} / \mathrm{v}))$ to yield the compound 2 (12.4 g, 99\%). An analytically pure compound was obtained by Kugelrohr sublimation $\left(78{ }^{\circ} \mathrm{C}, 5 \mathrm{~Pa}\right)$ as colorless crystals. Mp 120-121.5 ${ }^{\circ} \mathrm{C} .{ }^{1} \mathrm{H}$ NMR $(300 \mathrm{MHz}$, $\left.\mathrm{CDCl}_{3}\right): \delta 8.32(\mathrm{~s}, 1 \mathrm{H}), 6.33(\mathrm{~s}, 1 \mathrm{H}), 5.19($ br s, $1 \mathrm{H}), 3.10($ br s, $2 \mathrm{H}), 1.90\left(\mathrm{~A}_{3} \mathrm{X}, J=6.7 \mathrm{~Hz}\right.$, $1 \mathrm{H}), 0.99\left(\mathrm{~A}_{3} \mathrm{X}, J=6.6 \mathrm{~Hz}, 6 \mathrm{H}\right) .{ }^{13} \mathrm{C} \mathrm{NMR}\left(75 \mathrm{MHz}, \mathrm{CDCl}_{3}\right): \delta 163.5,158.4,49.1,28.2$, 20.2 (two peaks could not be identified due to broad resonances). IR (KBr): $v$ 3241, 3101, 3026, 2960, 2871, 1606, 1572, 1458, 1396, 1334, 602, 557, 458, $418 \mathrm{~cm}^{-1}$. FABMS m/z (\%): 186.12 (100) $\left[\mathrm{C}_{8} \mathrm{H}_{13}{ }^{35} \mathrm{ClN}_{3}\right]^{+}, 188.12$ (33) $\left[\mathrm{C}_{8} \mathrm{H}_{13}{ }^{37} \mathrm{ClN}_{3}\right]^{+}$. Anal. Calcd for $\mathrm{C}_{8} \mathrm{H}_{12} \mathrm{~N}_{3} \mathrm{Cl}$ : C, 51.76; H, 6.51; N, 22.63. Found: C, 51.84; H, 6.51; N, 22.64.

\section{4-Isobutylamino-6-methoxypyrimidine 3}

A three-necked flask was equipped with a nitrogen gas inlet, dropping funnel and reflux condenser with the top attached to a $\mathrm{CaSO}_{4}$ drying tube. The apparatus was dried with a heat gun under nitrogen flow. In the flask, sodium methoxide $(14.7 \mathrm{~g}, 0.272 \mathrm{~mol})$ was dissolved in dry $\mathrm{MeOH}(180 \mathrm{~mL})$ under nitrogen. To the clear solution, pyrimidine 2 (7.68 $\mathrm{g}, 41.4 \mathrm{mmol}$ ) was added in one portion. The mixture was refluxed for $12 \mathrm{~h}$. After cooling, the mixture was concentrated under reduced pressure. The residue was partitioned between water $(100 \mathrm{~mL})$ and ether $(100 \mathrm{~mL})$. The aqueous phase was extracted with ether $(100 \mathrm{~mL})$. The organic phase was dried over $\mathrm{Na}_{2} \mathrm{SO}_{4}$, filtered and evaporated. The obtained material was freeze-dried to give the product $\mathbf{3}$, which was purified by sublimation $\left(63{ }^{\circ} \mathrm{C}, 5 \mathrm{~Pa}\right)$ to give the compound $3(6.69 \mathrm{~g}, 89 \%)$ as a white solid. $\mathrm{Mp}$ 41-42 ${ }^{\circ} \mathrm{C} .{ }^{1} \mathrm{H}$ NMR $\left(300 \mathrm{MHz}, \mathrm{CDCl}_{3}\right): \delta 8.23(\mathrm{~s}, 1 \mathrm{H}), 5.62(\mathrm{~s}, 1 \mathrm{H}), 4.94(\mathrm{~s}, 1 \mathrm{H}), 3.91(\mathrm{~s}$, $3 \mathrm{H}), 3.02\left(\mathrm{~A}_{2} \mathrm{X}, J=6.3 \mathrm{~Hz}, 2 \mathrm{H}\right), 1.88\left(\mathrm{~A}_{3} \mathrm{X}, J=6.7 \mathrm{~Hz}, 1 \mathrm{H}\right), 0.98\left(\mathrm{~A}_{3} \mathrm{X}, J=6.6 \mathrm{~Hz}, 6 \mathrm{H}\right)$.

${ }^{13} \mathrm{C}$ NMR (75 MHz, $\left.\mathrm{CDCl}_{3}\right): \delta 170.3,164.3,157.7,84.3,53.5,49.4,28.1,20.3$. IR (KBr): $v$ 3248, 3098, 3008, 2955, 2930, 2905, 2871, 1612, 1548, 1509, 1478, 1442, 1398, 1358, 1335, 1305, 638, 589, 557, $473 \mathrm{~cm}^{-1}$. FABMS m/z: $182.18\left([\mathrm{M}+\mathrm{H}]^{+}, \mathrm{C}_{9} \mathrm{H}_{16} \mathrm{~N}_{3} \mathrm{O}\right)$. Anal. Calcd for $\mathrm{C}_{9} \mathrm{H}_{15} \mathrm{~N}_{3} \mathrm{O}$ : C, 59.64; H, 8.34; N, 23.19. Found: C, 59.85; H, 8.37; N, 23.04.

\section{4-Isobutylamino-6-oxopyrimidine 1c}

A solution of pyrimidine $3(5.43 \mathrm{~g}, 30.0 \mathrm{mmol})$ in $9 \mathrm{~N} \mathrm{HCl}(300 \mathrm{~mL})$ was refluxed for 1 h. After removing the solvent, the residue was dried in vacuo using a $\mathrm{KOH}$ trap. Then the product was dissolved in water $(20 \mathrm{~mL})$ and neutralized by aqueous $\mathrm{NaOH}$. The liberated material was collected by suction filtration to give the product 1c $(2.35 \mathrm{~g}, 47 \%)$. Recrystallization from water with charcoal treatment gave colorless prisms containing 0.25 molecule of water. Anhydrous 1c was obtained by drying at $120{ }^{\circ} \mathrm{C}$ in vacuo. $\mathrm{Mp}$ 222.5-223.5 ${ }^{\circ} \mathrm{C} .{ }^{1} \mathrm{H}$ NMR (300 MHz, DMSO-d $)$ ): $\delta 11.39$ (s, 1H), 7.78 (s, 1H), 6.98 (t, $J=$ 
$5.7 \mathrm{~Hz}, 1 \mathrm{H}), 4.90(\mathrm{~s}, 1 \mathrm{H}), 2.85($ br s, $2 \mathrm{H}), 1.78\left(\mathrm{~A}_{3} \mathrm{X}, J=6.7 \mathrm{~Hz}, 1 \mathrm{H}\right), 0.87\left(\mathrm{~A}_{3} \mathrm{X}, J=6.8\right.$ $\mathrm{Hz}, 6 \mathrm{H}) .{ }^{13} \mathrm{C}$ NMR $\left(75 \mathrm{MHz}, \mathrm{DMSO}-d_{6}\right): \delta 162.9,161.8,149.0,83.0,48.6,27.4,20.1$. CPMAS ${ }^{13} \mathrm{C}$ NMR (100.5 MHz): [ $\alpha$ crystals] $\delta 165.8,163.0,149.5,85.0,50.6,26.0,21.4$; [ $\beta$ crystals] $\delta 167.3,165.8,164.6,163.0,84.9,84.4,51.4,28.9,26.0,21.4$. IR (KBr): $v$ 3249, 3102, 3049, 2958, 2870, 2795, 2664, 1651, 1632, 1572, 1543, 1468, 1406, 1389, 1362, 1342, 1304, 592, 556, 512, $461 \mathrm{~cm}^{-1}$. FABMS $m / z: 168.16\left([\mathrm{M}+\mathrm{H}]^{+}, \mathrm{C}_{8} \mathrm{H}_{14} \mathrm{~N}_{3} \mathrm{O}\right)$. Anal. Calcd for $\mathrm{C}_{8} \mathrm{H}_{13} \mathrm{~N}_{3} \mathrm{O} \cdot 0.25 \mathrm{H}_{2} \mathrm{O}: \mathrm{C}, 55.96 ; \mathrm{H}, 7.92 ; \mathrm{N}, 24.47$. Found: $\mathrm{C}, 55.84 ; \mathrm{H}$, 7.90; N, 24.35. Anal. Calcd for $\mathrm{C}_{8} \mathrm{H}_{13} \mathrm{~N}_{3} \mathrm{O}$ : C, 57.46; H, 7.84; N, 25.13. Found: C, 57.43; $\mathrm{H}, 7.81 ; \mathrm{N}, 25.06$.

\section{X-ray crystallography}

\section{Crystal preparation}

The $\alpha$ and $\beta$ crystals were prepared in the following way. The compound 1c was dissolved in boiling nitrobenzene, and the solution was incubated at $35{ }^{\circ} \mathrm{C}$. When the concentration of 1c was at $0.024 \mathrm{M}, \beta$ crystals were predominantly formed, while above $0.033 \mathrm{M}$ both $\alpha$ and $\beta$ crystals formed. The light $\beta$ crystals, which floated near the surface, were scooped up and separated from the heavier $\alpha$ crystals.

$X$-ray diffraction data collections and structure solution

The X-ray data were collected on a Rigaku RAXIS-RAPID Imaging Plate diffractometer with graphite monochromated Mo $\mathrm{K} \alpha$ radiation $(\lambda=0.71069 \AA)$. The structure was solved using the direct method technique (SIR 97) and a full-matrix least squares refinement based on $F^{2}$. All non-hydrogen atoms were refined anisotropically, while the hydrogen atoms, all found in the difference Fourier map, were isotropically refined. The details of the X-ray analysis for the crystals of $1 \mathbf{c}$ (quarter hydrated, $\alpha$ and $\beta$ ) have been deposited as CCDC 724430, 724431 and 724432 can be obtained free of charge from the Cambridge Crystallographic Data Centre, 12 Union Road, Cambridge, CB2, 1EZ, UK (fax: (+44) 1223-336-033; e-mail: deposit@ccdc.cam.ac.uk) or at http://www.ccdc.cam.ac.uk/data_request/cif.

\section{Crystal data}

1c $0.25 \mathrm{H}_{2} \mathrm{O}: 4\left(\mathrm{C}_{8} \mathrm{H}_{13} \mathrm{ON}_{3}\right) \cdot \mathrm{H}_{2} \mathrm{O}, M_{\mathrm{r}}=686.86$, monoclinic, $C 2 / \mathrm{c}$ (no. 15), $a=14.8158(4), b$ $=18.4200(4), c=13.7700(3) \AA, \beta=104.7611(3)^{\circ}, U=3633.9(1) \AA^{3}, Z=4, T=113 \mathrm{~K}, D_{\mathrm{c}}$ $=1.255 \mathrm{~g} \mathrm{~cm}^{-3}, \mu(\mathrm{Mo} \mathrm{K} \alpha)=0.00 \mathrm{~cm}^{-1}, 2 \theta_{\max }=55.0^{\circ}, 17039$ reflections were collected, of which 4172 were unique, 330 parameters, GOF $=1.07, R_{1}=0.043(I>2(\sigma) I), w R_{2}=$ $0.125(I>2(\sigma) I)$, residual electron density: 0.51 and $-0.57 \mathrm{e}^{-3}$. CCDC 724430 . 
$1 c$ ( $\alpha$ form): $\mathrm{C}_{8} \mathrm{H}_{13} \mathrm{ON}_{3}, M_{\mathrm{r}}=167.21$, triclinic, $P_{\overline{1}}^{-}$(no. 2), $a=4.8006(2), b=8.3974(4), c$ $=11.4115(4) \AA, \alpha=68.879(3)^{\circ}, \beta=87.276(1)^{\circ}, \gamma=83.736(3)^{\circ}, U=426.54(3) \AA^{3}, Z=2$, $T=113 \mathrm{~K}, D_{\mathrm{c}}=1.302 \mathrm{~g} \mathrm{~cm}^{-3}, \mu(\mathrm{Mo} \mathrm{K} \alpha)=0.90 \mathrm{~cm}^{-1}, 2 \theta_{\max }=55.0^{\circ}, 3683$ reflections were collected, of which 1888 were unique, 161 parameters, $\mathrm{GOF}=1.62, R_{1}=0.042(I>2(\sigma) I)$, $w R_{2}=0.134(I>2(\sigma) I)$, residual electron density: 0.34 and $-0.16 \mathrm{e}^{-3}$. CCDC 724431.

$1 c$ ( $\beta$ form): $\mathrm{C}_{8} \mathrm{H}_{13} \mathrm{ON}_{3}, M_{\mathrm{r}}=167.21$, triclinic, $P \overline{1}$ (no. 2$), a=11.1904(5), b=11.9041(3)$, $c=12.6406(5) \AA, \alpha=109.066(1)^{\circ}, \beta=105.254(2)^{\circ}, \gamma=110.408(1)^{\circ}, U=1349.78(10) \AA^{3}$, $Z=6, T=113 \mathrm{~K}, D_{\mathrm{c}}=1.234 \mathrm{~g} \mathrm{~cm}^{-3}, \mu($ Mo K $\alpha)=0.85 \mathrm{~cm}^{-1}, 2 \theta_{\max }=55.0^{\circ}, 11749$ reflections were collected, of which 5950 were unique, 481 parameters, GOF $=1.66, R_{1}=$ $0.045(I>2(\sigma) I), w R_{2}=0.148(I>2(\sigma) I)$, residual electron density: 0.43 and $-0.41 \mathrm{e}^{-3}$. CCDC 724432.

\section{Pulsed field gradient NMR}

Diffusion experiments were recorded on a Jeol JNM-ECA 600 NMR spectrometer equipped with a pulse field gradient probe (TH5ATFG2). The pulse sequence was based on the stimulated echo and incorporated bipolar gradient pulses and a longitudinal eddy current delay. The sine gradient pulse was applied by varying the gradient strength from 0.01 to $0.9 \mathrm{~T} \mathrm{~m}^{-1}$. The ratio of the echo intensity between the presence $(I)$ and the absence $\left(I_{0}\right)$ of the a pulsed gradient is given by ${ }^{2,3}$

$$
\ln \left(I / I_{0}\right)=-\gamma^{2} D \delta^{2} g^{2}(4 \Delta-\delta) / \pi^{2}
$$

where $\delta$ is the duration of the field gradient with magnitude $g, \gamma$ is the gyromagnetic ratio, $D$ is the diffusion coefficient, and $\Delta$ is the separation between the two gradient pulses. The $\delta$ was in the range of $0.36-1.4 \mathrm{~ms}$. The $\Delta$ was $100 \mathrm{~ms}$ and $200 \mathrm{~ms}$ for a $0.10 \mathrm{M}$ and a $5.0 \times$ $10^{-3} \mathrm{M}$ solution of $1 \mathrm{c}$, respectively. For a $5.0 \times 10^{-3} \mathrm{M}$ solution of dichloropyrimidine, the $\Delta$ used was $300 \mathrm{~ms}$. The decay curve was obtained by plotting the signal intensity as a function of the gradient strength. The resulting decay was analyzed by fitting to eq. (1) using a nonlinear least-square method implemented in the NMR software of Delta, Jeol. The reported diffusion coefficient is the mean of at least three measurements. 


\section{Determination of the solubility of the $\alpha$ and $\beta$ crystals in nitrobenzene}

Each of the separated crystals of 1c was powdered and ca. $10 \mathrm{mg}$ was put in nitrobenzene $(2 \mathrm{~mL})$ at the specific thermostated temperature until saturation $(18 \mathrm{~h}$; an equilibrium was confirmed by several experiments) with the crystals present in excess. After filtering off the undissolved crystals, $0.60 \mathrm{~mL}$ of the solution was taken and diluted with $40 \mathrm{~mL}$ of $n$-hexane to precipitate the crystals. The crystals were collected at the bottom of a test tube by centrifugation, and the supernatant solvents were removed. After washing by 3 cycles of $n$-hexane addition, centrifugation and removal of the supernatant liquid, the residual crystals were dried. However, since the amount of crystals so obtained was minute, and even a trace of residual nitrobenzene could not be ignored, the amount of crystals was determined by HPLC in the following manner.

The collected crystals were dissolved in methanol and mixed with a fixed amount of dimethyl isophthalate (DMIP) as an internal standard, and the solution was diluted to 10 $\mathrm{mL}$ to give DMIP in a concentration of $4.40 \times 10^{-4} \mathrm{M}$. The HPLC analyses of the solutions were performed on a Hitachi EZChrom Elite/LaChrom system equipped with an analytical column (Nacalai Tesque, Cosmosil 5C18-AR-II, $20 \times 250 \mathrm{~mm}$ ). The mobile phase was $30 \%$ aqueous $\mathrm{MeOH}$ at a flow rate of $5 \mathrm{~mL} \mathrm{~min}^{-1}$. In order to make the HPLC peak areas correspond to the amount of 1c, a calibration line was prepared using standard solutions containing the accurately weighed 1c and DMIP in $30 \%$ aqueous $\mathrm{MeOH}$ in the concentration range of $0.20-9.70 \times 10^{-4} \mathrm{M}$ and $1.10 \times 10^{-3} \mathrm{M}$, respectively. An example of the chromatogram of a standard solution is shown in Figure S7 (retention time of 1c and DMIP were 12.6 and $27.3 \mathrm{~min}$, respectively). The concentration of $\mathbf{1 c}$ in the sample solution was estimated by comparison with the calibration line for 1c prepared by plotting the ratio of the peak area of $1 \mathrm{c}$ to that of the DMIP versus the ratio of the concentration of 1c to that of DMIP. However, when the solubility of 1c was increased at higher temperatures, the ratio to DMIP became too large, and another calibration line, obtained by plotting the peak area against the concentration of $\mathbf{1 c}$, was used instead (the linearity in the concentration region used was confirmed to be high: a correlation coefficient $R_{2}>$ 0.998, Figure S8). The resultant chromatographic data are summarized in Table S1.

\section{Reference}

(1) Hull, R. J. Chem. Soc. 1951, 2214.

(2) Stejskal, E. O.; Tanner, J. E. J. Chem. Phys. 1965, 42, 288-292.

(3) Price, W. S.; Kuchel, P. W. J. Magn. Reson. 1991, 94, 133-139. 
(a)

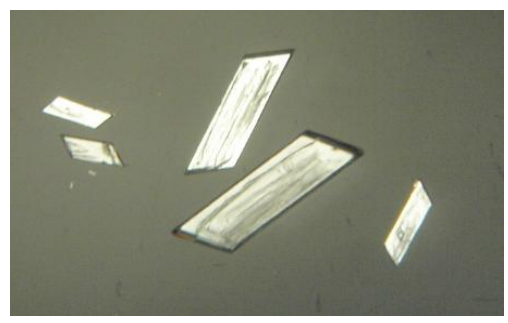

(b)

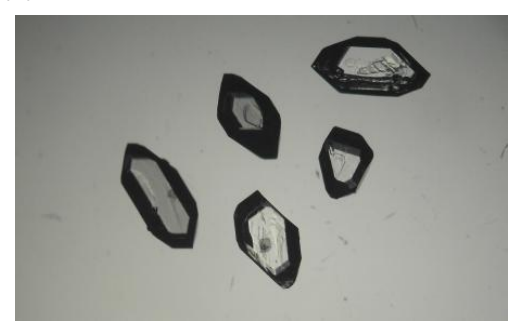

Figure S1. Photomicrograph of the polymorphic crystals of 1c: (a) $\alpha$ crystals and (b) $\beta$ crystals. 
(a)

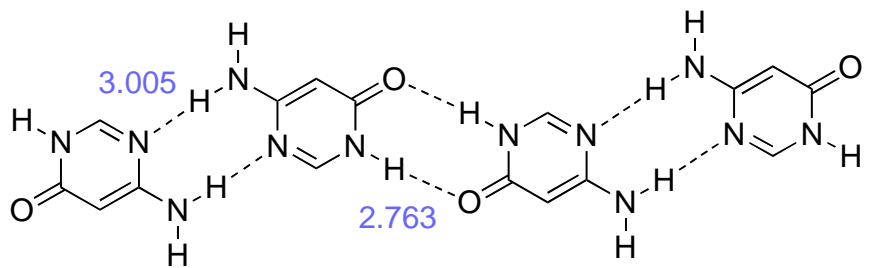

(b)

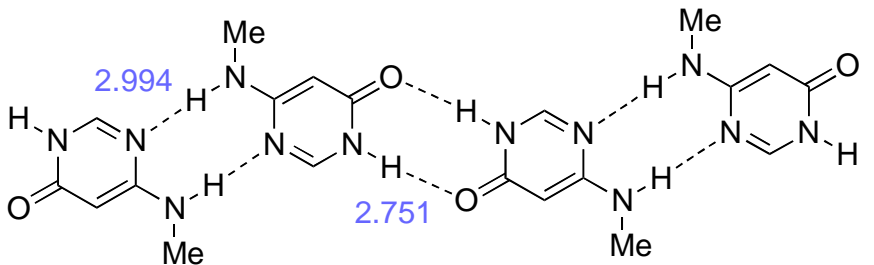

(c)

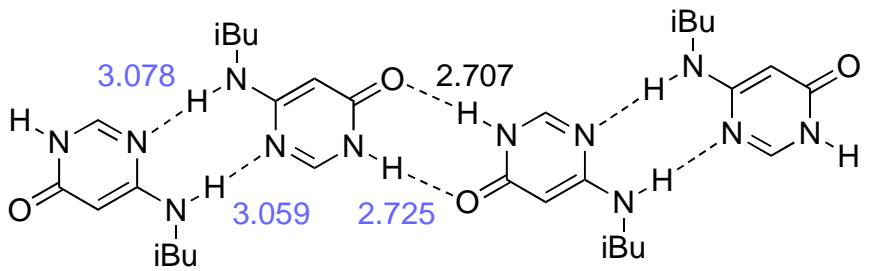

(d)

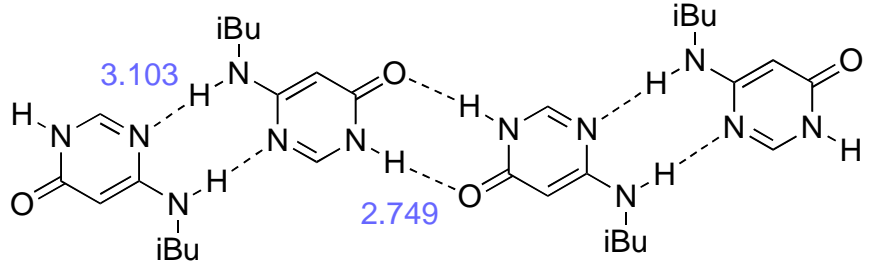

Figure S2. Variations in the distances of hydrogen bonds for the linear tape structures: (a) 1a, (b) $1 \mathbf{b} \cdot 2 \mathrm{H} 2 \mathrm{O}$, (c) $1 \mathbf{c} \cdot 0.25 \mathrm{H} 2 \mathrm{O}$ and (d) $1 \mathbf{c}$. 


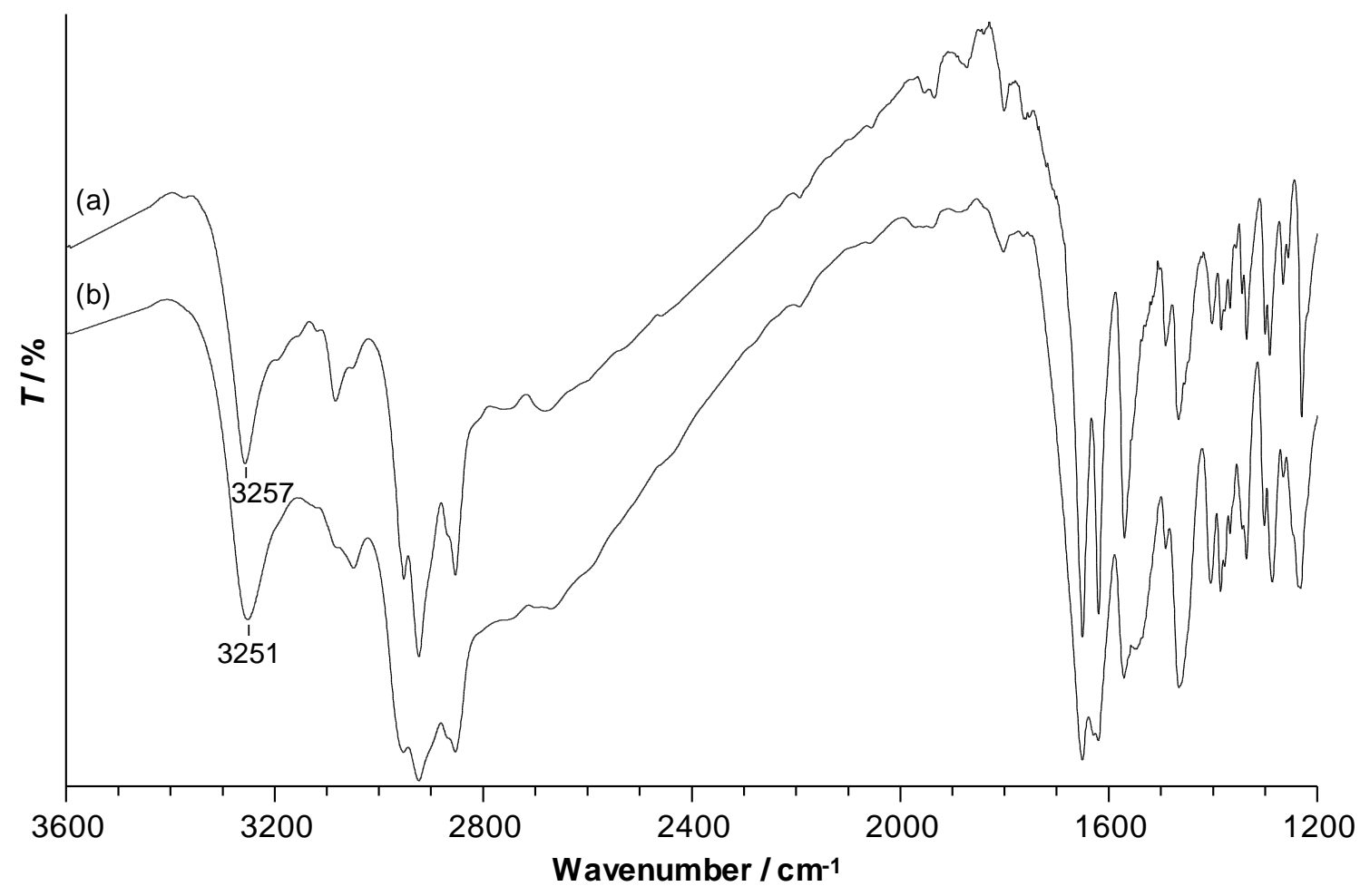

Figure S3. FT-IR spectra of 1c. (a) $\alpha$ and (b) $\beta$ crystals. 


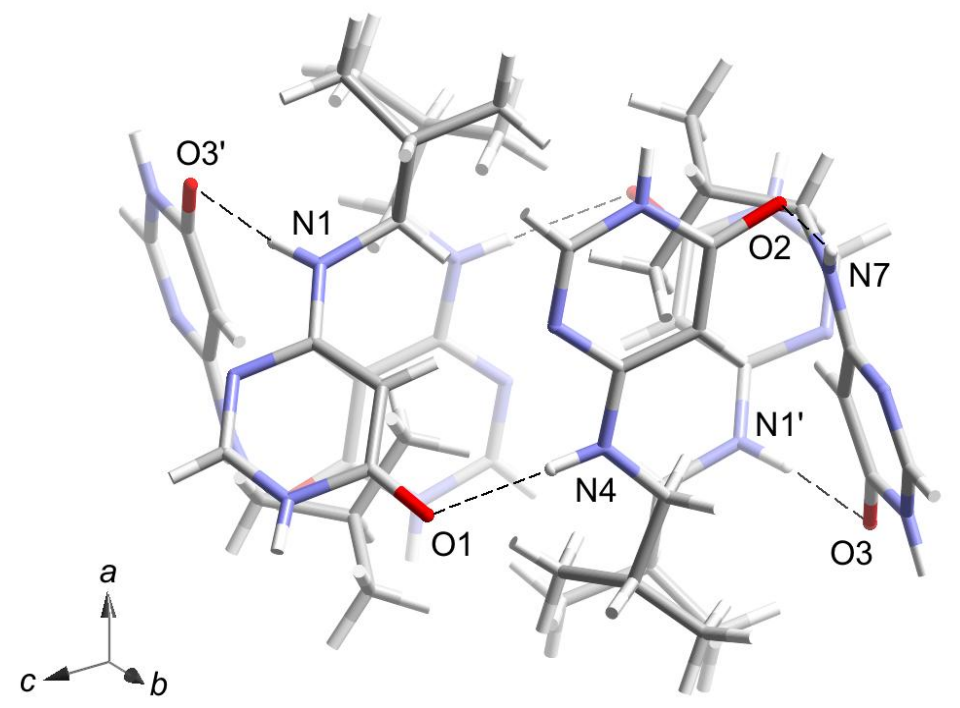

Figure S4. Perspective view of the hexameric ball-like assembly of $1 \mathrm{c}$ in the $\beta$ crystals. Dashed lines represent the hydrogen bonding. 


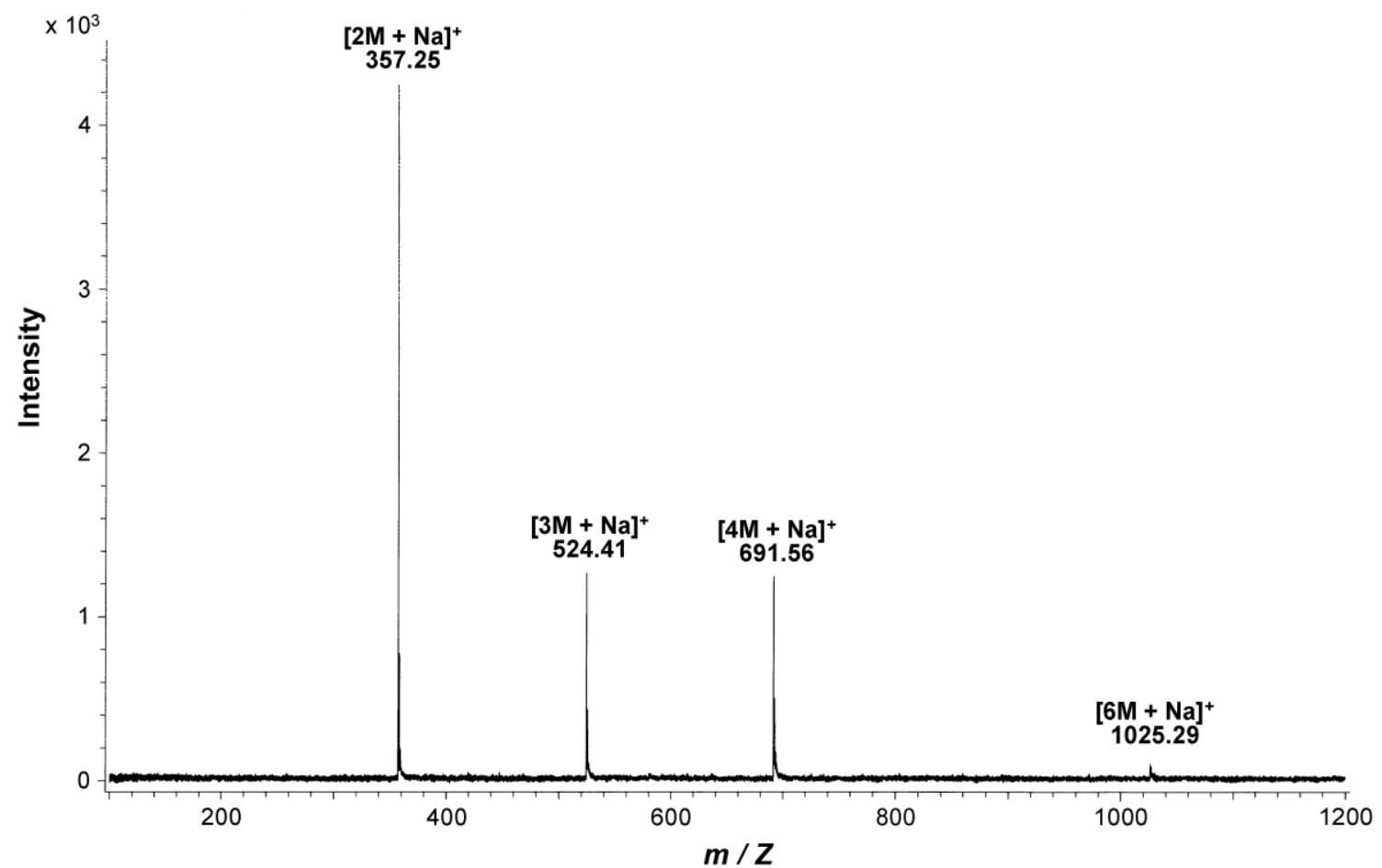

Figure S5. Electrospray ionization mass spectrum of $1 \mathrm{c}$ in ethanol $\left(1 \times 10^{-4} \mathrm{M}\right)$. 


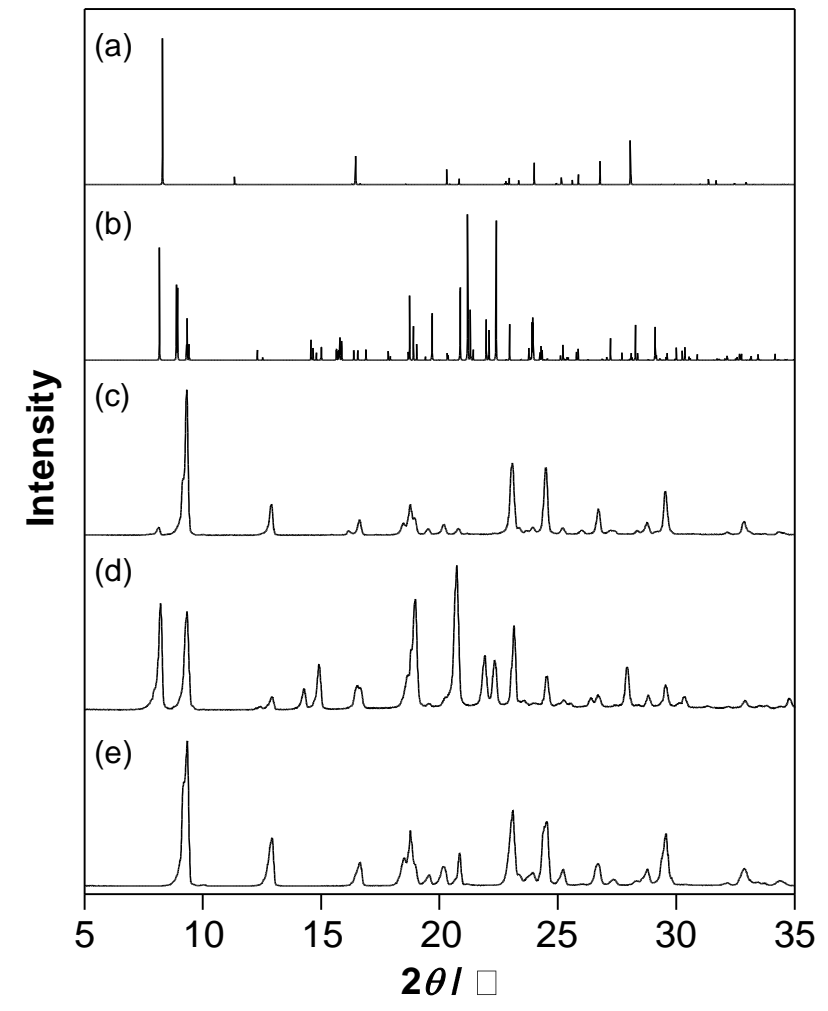

Figure S6. Powder XRD patterns of 1c. Simulated powder patterns of the polymorphic (a) the plate and (b) the trapezoid crystals calculated from their crystallographic data. Observed powder XRD patterns of the crystal separated. (c) $\alpha$ crystals, (d) $\beta$ crystals, and (e) crystals obtained by recrystallization from $\mathrm{MeOH}$. 


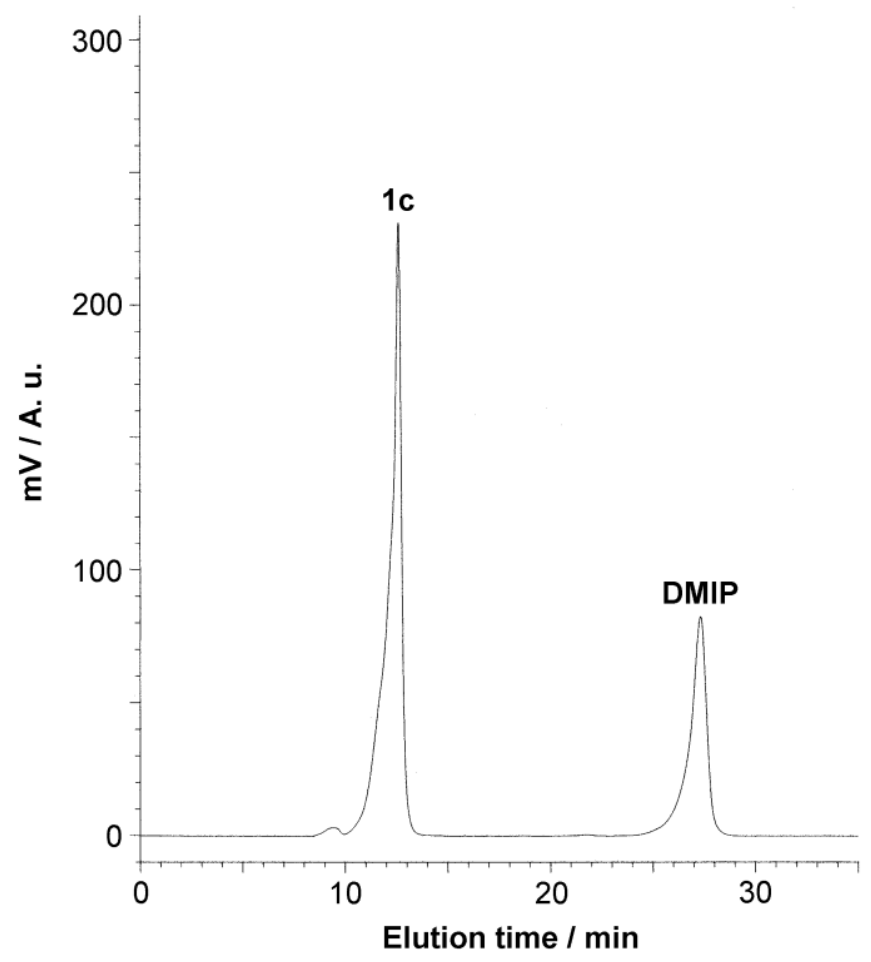

Figure S7. Representative chromatogram of 1c with dimethyl isophthalate (DMIP) in $30 \%$ aqueous $\mathrm{MeOH}$. 
(a)

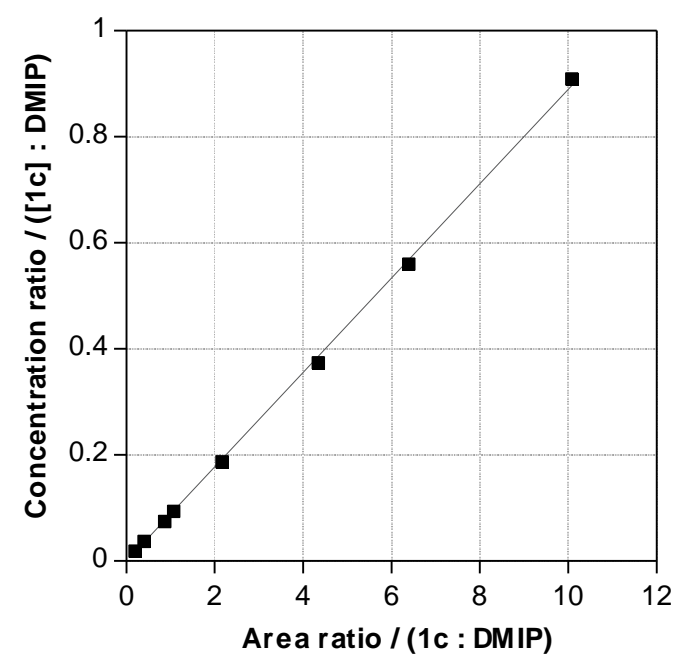

(b)

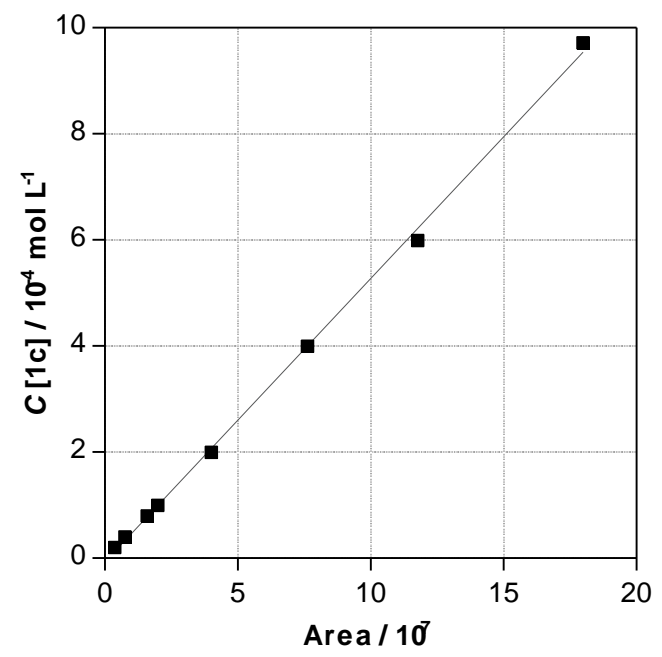

Figure S8. (a) The calibration line obtained by plotting the ratios of the peak areas as a function of concentration ratio of $\mathbf{1} \mathbf{c}$ to dimethyl isophthalate (DMIP) used as the internal standard. (b) The calibration line for 1c obtained by plotting the peak area versus the known concentration of $\mathbf{1 c}$. 
Table S1. Chromatographic profiles of the analytes containing 1c and DMIP.

\begin{tabular}{|c|c|c|c|c|c|}
\hline $\begin{array}{c}\text { Crystal } \\
\text { form }\end{array}$ & $\begin{array}{c}\text { Temperature } \\
{\left[{ }^{\circ} \mathrm{C}\right]}\end{array}$ & $\begin{array}{l}\text { Peak area of } \\
\text { 1c }\left[\times 10^{6}\right]\end{array}$ & $\begin{array}{l}\text { Peak area of } \\
\text { DMIP } \quad[\times \\
\left.10^{6}\right]\end{array}$ & $\begin{array}{l}\text { Area ratio } \\
(\mathbf{1 c}: \text { DMIP) }\end{array}$ & $\begin{array}{l}\text { Concentration } \\
\text { of } \mathbf{1 c}[\mathrm{M}]\end{array}$ \\
\hline \multirow[t]{4}{*}{$\alpha$} & 15 & 2.995 & 8.114 & 0.369 & $6.1 \times 10^{-5}$ a \\
\hline & 25 & 6.936 & 7.757 & 0.894 & $5.9 \times 10^{-4} \mathrm{a}$ \\
\hline & 37 & 92.90 & 6.998 & 13.3 & $8.2 \times 10^{-3} \mathrm{~b}$ \\
\hline & 47 & 169.8 & 7.367 & 23.1 & $3.0 \times 10^{-2} \mathrm{~b}$ \\
\hline \multirow[t]{4}{*}{$\beta$} & 15 & 1.675 & 8.019 & 0.209 & $3.4 \times 10^{-5} \mathrm{a}$ \\
\hline & 25 & 1.573 & 8.141 & 0.193 & $1.3 \times 10^{-4 \mathrm{a}}$ \\
\hline & 37 & 57.80 & 7.722 & 7.49 & $5.0 \times 10^{-3 b}$ \\
\hline & 47 & 116.0 & 6.076 & 19.1 & $2.0 \times 10^{-2 b}$ \\
\hline
\end{tabular}

